\title{
Antimicrobial Activities and Some Flavonoids in Extracts of Some Medicinal Plants
}

\author{
Izzet Şener*1, Mahmut Gür², Didem Verep², Kerim Güney ${ }^{3}$, Ergin Murat Altuner ${ }^{4}$ \\ ${ }^{1}$ Department of Food Engineering, Faculty of Engineering and Architecture, Kastamonu University, TURKEY \\ ${ }^{2}$ Department of Forest Industrial Engineering, Faculty of Forestry, Kastamonu University, TURKEY \\ ${ }^{3}$ Department of Forest Engineering, Faculty of Forestry, Kastamonu University, TURKEY; \\ ${ }^{4}$ Faculty of Science-Arts, Department of Biology, Kastamonu University, TURKEY
}

\begin{abstract}
Origanum majorana, Melissa officinalis, Anthemis cotula and Avena sativa were extracted by using $65 \%$ ethanol to isolate their active constituents. The antimicrobial activities of extracts were investigated against 15 microorganisms by using the disk diffusion method, MIC (Minimum Inhibitory Concentration), MBC (Minimum Bactericidal Concentration) and MFC (Minimal Fungicidal Concentration) tests. Furthermore, the presence of some flavonoids were analyzed by using HPLC. It was determined flavonoids in the extracts of $O$. majorana, $M$. officinalis, $A$. cotula and $A$. sativa. As a results it was observed that $O$. majorana was active against Staphylococcus aureus, Enterococcus faecium, Enterococcus faecalis, Salmonella typhimurium and Pseudomonas aeruginosa, where M. officinalis was active against Enterococcus faecium and Enterococcus faecalis. On the other hand, both $A$. cotula and $A$. sativa were observed to be active against Enterococcus faecium. The extracts of plant samples showed antibacterial activity against tested microorganisms at different levels.
\end{abstract}

Keywords: Origanum majorana, Melissa officinalis, Anthemis cotula, Avena sativa, Antimicrobial activity, Flavonoid.

\section{INTRODUCTION}

For a long period of time, plants have been a valuable source of natural products for maintaining human health. Nowadays, the use of phytochemicals for pharmaceutical purpose has gradually increased in many countries. According to World Health Organization (WHO) medicinal plants would be the best source to obtain a variety of drugs. About $80 \%$ of individuals from developed countries use medicinal plants. ${ }^{1}$

The use of crude extracts of plants parts and phytochemicals, of known antimicrobial properties, can be of great significance in the therapeutic treatments. In recent years, a number of studies have been conducted in various countries to prove such efficiency. Many plants have been used because of their antimicrobial traits, which are due to the secondary metabolites synthesized by the plants.,3 These products are known by their active substances like, phenolic compounds which are part of the essential oils, as well as in tanning. ${ }^{4}$ The screening of plant products for antimicrobial activity have shown that the higher plants represent a potential source of novel antibiotic prototypes. There has been an increasing incidence of multiple resistances in human pathogenic microorganisms in recent years, largely due to indiscriminate use of commercial antimicrobial drugs commonly employed in the treatment of infectious diseases. ${ }^{5}$ This has forced scientist to search for
DOI: 10.5530/ijper.51.3s.20 Correspondence: Izzet Şener,

Department of Food Engineering, Faculty of Engineering and Architecture, Kastamonu University, TURKEY Phone no: +90-3662802960 E-mail: isener@kastamonu. edu.tr 
new antimicrobial substances from various sources like the medicinal plants. Plant produces a wide variety of secondary metabolites which are used either directly as precursors or as lead compounds in the pharmaceutical industry. It is expected that plant extracts showing target sites other than those used by antibiotics will be active against drug resistant microbial pathogens. However, very little information is available on such activity of medicinal plants and out of the 400.000 plant species on earth, only a small number has been systematically investigated for their antimicrobial activities. ${ }^{6}$

\section{MATERIALS AND METHODS}

\section{Plant Samples}

Origanum majorana, Melissa officinalis, Anthemis cotula and Avena sativa were purchased from Özşen Lokman Hekim Company located in Ankara/Turkey, Gimat at 2016.

\section{Extraction method}

The plants were washed with water and air dried under shade. The dried plant sample were ground in a mixer. 10-30 g ground samples were extracted with $250 \mathrm{~mL}$ of ethanol $(65 \%)$ in a Soxhlet apparatus by continuous heat extraction for $24 \mathrm{~h}$. Extracts were prepared according to previous studies and stored at $4^{\circ} \mathrm{C}$ for further studies. ${ }^{7}$

\section{Determination of Antimicrobial Activities Preparation of Extract Stock}

Extract stocks to test the antimicrobial activity were prepared by dissolving $1 \mathrm{mg}$ of extract in each $3 \mathrm{~mL}$ of ethanol for disk diffusion test, where the solvent was distilled water for MIC tests. The extract stock prepared for MIC test was sterilized through $0.45 \mu \mathrm{m}$ filter (Millipore).

\section{Strains}

Bacillus subtilis DSMZ 1971, Candida albicans DSMZ 1386, Enterobacter aerogenes ATCC 13048, Enterococcus faecalis ATCC 29212, Enterococcus faecium, Escherichia coli ATCC 25922, Klebsiella pneumoniae, Pseudomonas aeruginosa DSMZ 50071, Pseudomonas fluorescens P1, Salmonella enteritidis ATCC 13075, Salmonella infantis, Salmonella kentucky, Salmonella typhimurium SL1344, Staphylococcus aureus ATCC 25923 and Staphylococcus epidermidis DSMZ 20044 were used in the study.

\section{Preparation of Inocula}

All strains were incubated according to their requirements as it was previously mentioned. ${ }^{7}$

The inoculate was prepared according to previous studies and adjusted. ${ }^{89}$ Thus standard inoculate contained adjusted number of microorganisms. ${ }^{10,11}$

\section{Disk diffusion test}

The disk diffusion test was applied as it was mentioned in the previous studies. ${ }^{12,13} 20,50$ and $100 \mu \mathrm{L}$ of extracts were loaded on sterile disks as mentioned before. ${ }^{14}$ The inoculation process was described as in the previous studies. ${ }^{13}$ Inhibition zones were defined in $\mathrm{mm}^{.15}$

\section{Minimum Inhibitory Concentration (MIC) Test}

A broth micro-dilution MIC test was applied as mentioned before. ${ }^{16}$ Two-fold dilutions of the extracts were prepared ranging from $33 \mathrm{mg} / \mathrm{mL}$ to $6.50 \mu \mathrm{g} / \mathrm{mL}$.

\section{Minimum Bactericidal/Fungicidal Concentration (MBC/MFC) Test}

The wells, where no visual growth were observed in MIC test were used for further analysis called MBC and MFC tests, which were conducted according to previous studies. ${ }^{17}$

\section{Controls}

Empty disks and sterilized broth medium were used as negative controls, where broth medium inoculated with each microorganism was used as positive control of microorganisms. ${ }^{18,19}$

\section{Statistics}

All tests were done in triplicates. Statistical analysis was conducted as mentioned in previous studies. ${ }^{20} p$ $<0.05$ was considered as statistically significant.

\section{HPLC Analysis}

HPLC analysis were carried out by using an Agilent Eclipse XDB C18 $5 \mu \mathrm{m}$ with 4.6 × $250 \mathrm{~mm}$ column and studied at the column temperature of $30{ }^{\circ} \mathrm{C}$. Flavonoids measurements were determined at $280 \mathrm{~nm}$ after $20 \mu \mathrm{L}$ injection volume. Standard solvents were prepared in the ethanol-distilled water (65-35) mixture. For HPLC analysis, mobile phase-A containing water- $10 \%$ formic acid (95-5), mobile phase-B containing acetonitrile- $10 \%$ formic acid (5-95) were used. Mobil phases were flowed for during $39 \mathrm{~min}$.

\section{RESULT AND DISCUSSION}




\begin{tabular}{|c|c|c|c|c|c|c|c|c|}
\hline & $\begin{array}{c}\text { Catechin } \\
(\mu \mathrm{g} / \mathrm{g})\end{array}$ & $\begin{array}{c}\text { Epicatechin } \\
\qquad(\mu g / g)\end{array}$ & $\begin{array}{l}\text { Rutin } \\
(\mu \mathrm{g} / \mathrm{g})\end{array}$ & $\begin{array}{c}\text { Naringin } \\
(\mu \mathrm{g} / \mathrm{g})\end{array}$ & $\begin{array}{c}\text { Myricetin } \\
(\mu \mathrm{g} / \mathrm{g})\end{array}$ & $\begin{array}{l}\text { Luteolin } \\
(\mu \mathrm{g} / \mathrm{g})\end{array}$ & $\begin{array}{l}\text { Naringenin } \\
(\mu \mathrm{g} / \mathrm{g})\end{array}$ & $\begin{array}{c}\text { Apigenin } \\
(\mu \mathrm{g} / \mathrm{g})\end{array}$ \\
\hline O. majorana & 17.23 & - & 18.34 & 0.79 & 34.22 & 33.55 & 0.70 & 2.08 \\
\hline M. officinalis & - & - & 19.06 & 10.50 & 22.85 & 64.17 & 961.75 & - \\
\hline A. cotula & - & 0.81 & 4.51 & 1.41 & 40.32 & 1.42 & 0.48 & 0.21 \\
\hline A. sativa & - & - & - & - & 1.47 & 0.13 & 0.36 & 0.58 \\
\hline
\end{tabular}

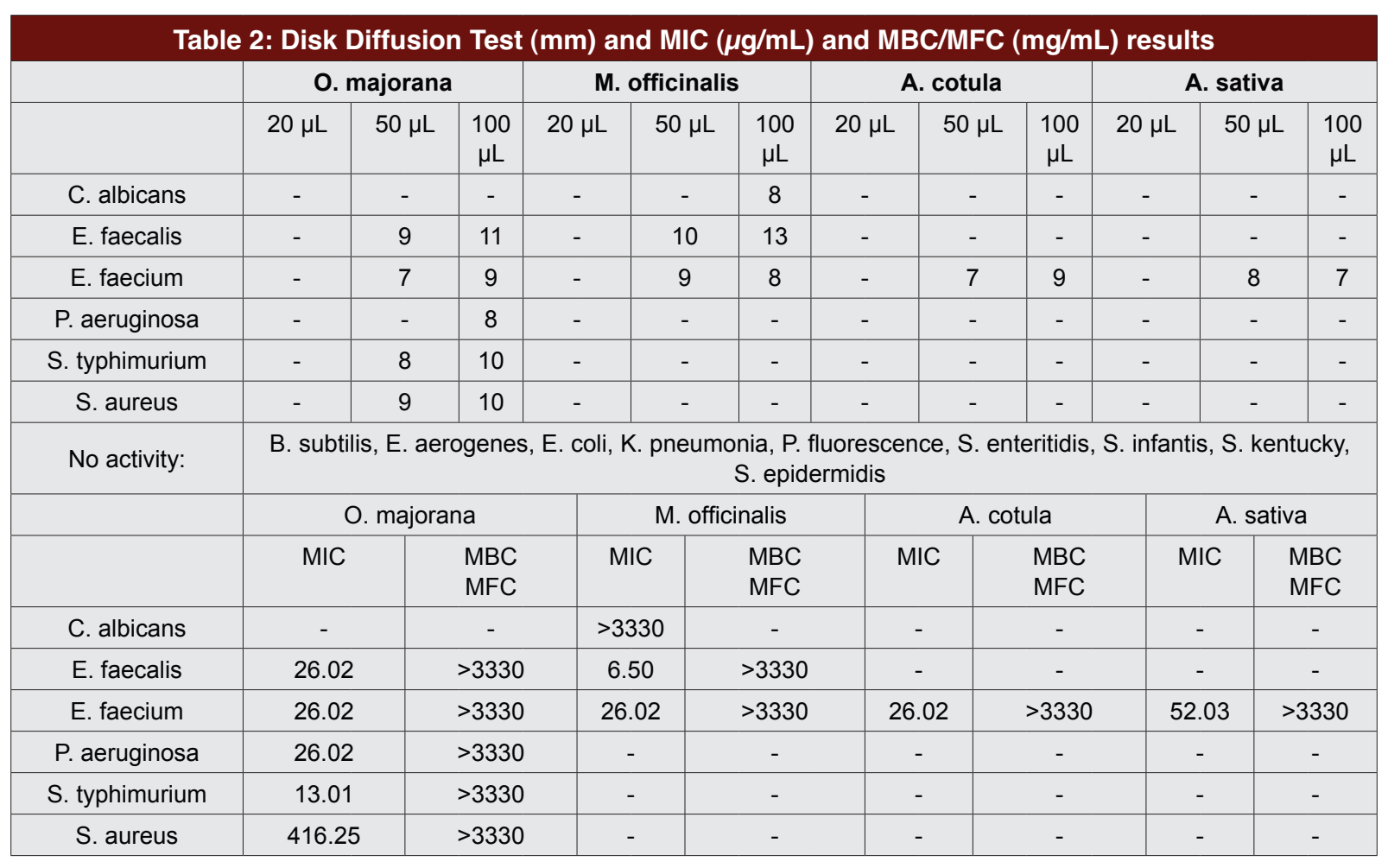

The HPLC results of the extracts are presented in Table 1 , and the antimicrobial activity test results are presented in Table 2.

While myricetin, luteolin and naringenin were detected in all extracts, catechin was only determined in extract of $O$. majorana. Epicatechin was only found in extract of $A$. cotula. Rutin and naringenin in other extracts apart from A. sativa, apigenin in other extracts apart from M. officinalis, were detected. The most abundant flavonoids were observed as myricetin (in extracts of $A$. cotula and O. majorana), luteolin and naringenin (in extract of M. officinalis) in Table1. And Also, disk diffusion test results given in Table 2 show that $O$. majorana is active against E. faecalis, E. faecium, P. aeruginosa, S. typhimurium and
S. aureus with inhibition zones between 7-11 mm, where $M$. officinalis is active against C. albicans, E. faecalis and E. faecium with inhibition zones between of $8-13 \mathrm{~mm}$. On the other hand, A. cotula was observed to be active against only E. faecium with inhibition zones between 7-9 mm depending on the amount of extract loaded on disks, where $A$. sativa was observed to be active against E. faecium with inhibition zones between 7-8 $\mathrm{mm}$.

To the extracts and microorganism combination which presented antimicrobial activity were chosen for MIC value determination. Results given in Table 2 show that O. majorana is active against E. faecalis, E. faecium, $P$. aeruginosa, $S$. typhimurium and $S$. aureus with MIC values of $26.02 \mu \mathrm{g} / \mathrm{mL}, 26.02 \mu \mathrm{g} / \mathrm{mL}, 26.02 \mu \mathrm{g} / \mathrm{mL}$, 
$13.01 \mu \mathrm{g} / \mathrm{mL}$ and $416.25 \mu \mathrm{g} / \mathrm{mL}$ respectively, where M. officinalis is active against C. albicans, E. faecalis and E. faecium with MIC values of $>3330 \mu \mathrm{g} / \mathrm{mL}, 6.50 \mu \mathrm{g} / \mathrm{mL}$ and $26.02 \mu \mathrm{g} / \mathrm{mL}$ respectively. On the other hand, $A$. cotula was observed to be active against only E. faecium with MIC value of $26.02 \mu \mathrm{g} / \mathrm{mL}$, where $G$. A. sativa was observed to be active against E. faecium with a MIC value of $52.03 \mu \mathrm{g} / \mathrm{mL}$.

$\mathrm{MBC} / \mathrm{MFC}$ test showed that all the MIC values observed were bacteriostatic/fungistatic concentrations, which means they only inhibit the reproduction of microorganisms. On the other hand, it wasn't possible to identify the "cidal" concentrations for all plant extracts and microorganism combinations, which presented an activity in MIC test, and were given as MBC/MFC $>3330$ $\mu \mathrm{g} / \mathrm{mL}$.

\section{CONCLUSION}

Catechin and epicatechin are the least common flavonoids in the studied plants, whereas myricetin, luteolin and naringenin were found as the most common flavonoids. However, the plant extracts seem to be rich in the flavonoids studied. The active compounds and their mode of actions especially for $O$. majorana needed to be analyzed in further studies.

\section{ACKNOWLEDGEMENT}

Authors thank to Kastamonu University.

\section{CONFLICT OF INTEREST}

None

\section{ABBREVIATION USED}

HPLC: High Performance Liquid Chromatography.

\section{REFERENCES}

1. Ellof JN. Which extractant should be used for the screening and isolation of antimicrobial components from plants? J. of Ethanopharmacol. 1998;60(1):1-8.
2. Yadav P, Malpathak N. Estimation of Antioxidant Activity and Total Phenol, Flavonoid Content among Natural Populations of Caper (Capparis moonii, Wight) from Western Ghats Region. Indian Journal of Pharmaceutical Education and Research. 2016;50(3):495-501

3. Tian S, Shi Y, Zhou X, Ge L, Upur H. Total polyphenolic (flavonoids) content and antioxidant capacity of different Ziziphora clinopodioides Lam. extracts. Phcog Mag. 2011;7(25):65-8

4. Pawar CR, Surana SJ. Antioxidant Properties of the Methanol Extract of the Wood and Pericarp of Caesalpinia decapetala. J Young Pharm. 2010;2(1):459.

5. Sak K. Cytotoxicity of dietary flavonoids on different human cancer types. Phcog Rev 2014;8(16):122-46.

6. Sanjeet KS, Kumar SS. Phytochemical and antibacterial efficacy of Hevea brasiliensis Journal of Chemical and Pharmaceutical Research. 2015;7(12):777-783.

7. Canlı K, Altuner EM, Akata I. Antimicrobial screening of Mnium stellare. Bangladesh Journal of Pharmacology. 2015;10(2):321-325.

8. Hammer KA, Carson CF, Riley TV. Antimicrobial activity of essential oils and other plant extracts. Journal of Applied Microbiology. 1999;86(6):985-990.

9. Altuner EM, Akata I, Canli K. In vitro antimicrobial screening of Cerena unicolor (Bull.) Murrill (Polyporaceae Fr. Ex Corda). Fresen. Environ. Bullet. 2012;21(1B):3704-10.

10. Canlı K, Akata I, Altuner EM. In vitro antimicrobial activity screening of Xylaria hypoxylon. African Journal of Traditional, Complementary and Alternative Medicines. 2016; 13(4):42-46.

11. Canlı K, Yetgin A, Akata I, Altuner EM. In vitro antimicrobial screening of Aquilaria agallocha roots. African Journal of Traditional, Complementary and Alternative Medicines. 2016;13(5):178-181.

12. Andrews JM. BSAC standardized disc susceptibility testing method (version 6). Journal of Antimicrobial Chemotherapy. 2003;60:20-41.

13. IIlhan S, Savaroğlu F, Çolak F, Iscen CF, Erdemgil FZ. Antimicrobial activity of Palustriella commutata (Hedw.) Ochyra extracts (Bryophyta). Turk. J. Biol. 2006;30(3):149-152.

14. Altuner EM, Akata I. Antimicrobial activity of some macrofungi extracts. Sakarya Üniversitesi Fen Bilimleri Enstitüsü Dergisi. 2010;14(1):45-9.

15. Altuner EM, Canli K, Akata I. Antimicrobial screening of Calliergonella cuspidata, Dicranum polysetum and Hypnum cupressiforme. Journal of Pure and Applied Microbiology. 2014;8(1):539-45.

16. Balouiri M, Sadiki M, Ibnsouda SK. Methods for in vitro evaluating antimicrobial activity: A review. Journal of Pharmaceutical Analysis. 2016;6(2):71-9.

17. Altuner EM, Çetin B. Antimicrobial activity of Thuidium delicatulum (Bryopsida) extracts. Kafkas Üniversitesi Fen Bilimleri Enstitüsü Dergisi. 2009;2(2):85-92.

18. Altuner EM. Investigation of antimicrobial activity of Punica granatum L. fruit peel ash used for protective against skin infections as folk remedies especially after male circumcision. African Journal of Microbiology Research. 2011;5(20):3339-42.

19. Canlı K, Yetgin A, Akata I, Altuner EM. In vitro antimicrobial activity of Angelica sylvestris roots. International Journal of Biological Sciences. 2016;1(1):1-7.

20. Canlı K, Altuner EM, Akata I, Türkmen Y, Üzek U. In vitro antimicrobial screening of Lycoperdon lividium and determination of the ethanol extract composition by gas chromatography/mass spectrometry. Bangladesh Journal of Pharmacology. 2016;11(2):389-94. 


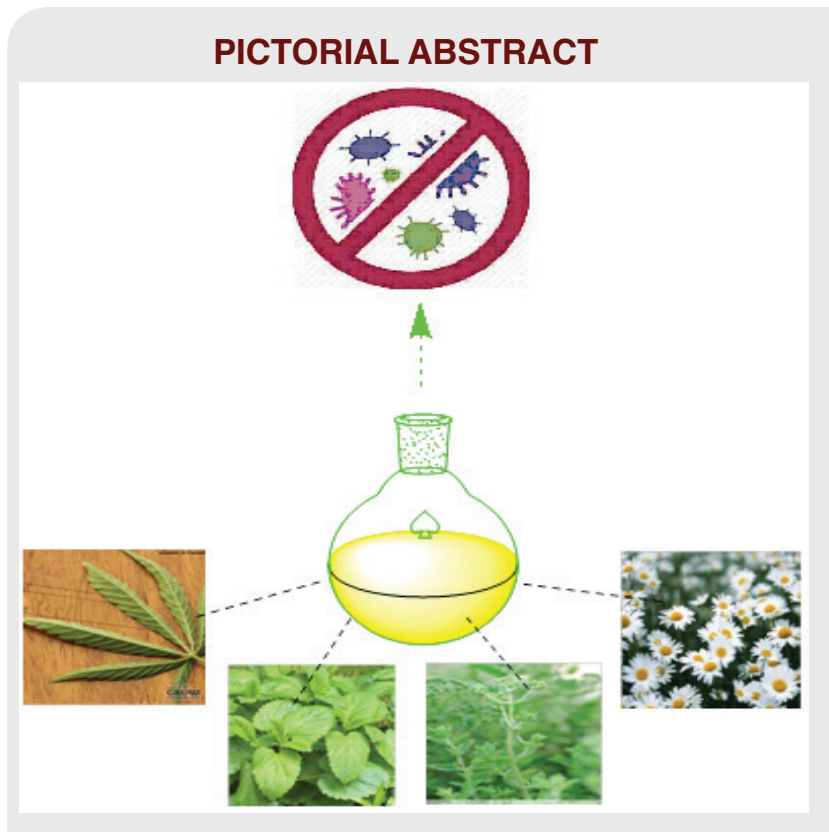

\section{SUMMARY}

- Origanum majorana, Melissa officinalis, Anthemis cotula and Avena sativa were extracted

- The antimicrobial activities were investigated against 15 microorganisms by using the disk diffusion method, MIC (Minimum Inhibitory Concentration), MBC (Minimum Bactericidal Concentration) and MFC (Minimal Fungicidal Concentration) tests.

- The presence of some flavonoids were analyzed by using HPLC.

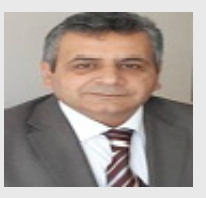

Dr. İzet Șener is presently working as Professor in Department of Food Engineering at Kastamonu University, Kastamonu, Turkey. His research interests are currently focused on macrocyclic chemistry, heterocyclic chemistry and azo dyes. He has published a number of publications in different journals in national and international repute.

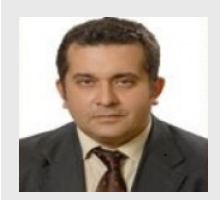

Mahmut GÜR has been working as Assistant Professor in Kastamonu University at Forest Industrial Engineering department, Kastamonu. He is interesting in the development of synthetic molecules. He has published a number of publications in different journals in national and international repute.

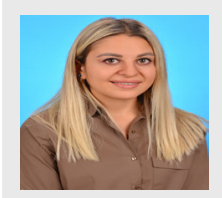

Didem Verep graduated with a master's degree in forest products chemistry department of forest industry engineering, Kastamonu University. Her thesis is "The Determination of Antioxidant Activity of Some Medicinal Plants and Identifying Species by HPLC Of Some Flavonoids".

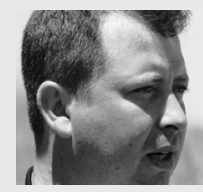

Kerim GÜNEY has been working as Assistant Professor at Botanic department, Forest Engineering Faculty in Kastamonu University. Kerim Güney has many publications on flora, vegetation, biodiversity and medical and aromatic plants.

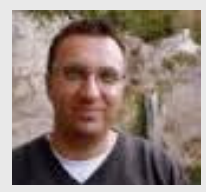

Ergin Murat Altuner has been interesting antioxidant and antimicrobial activities of natural and synthetic compounds. These interests expanded at the Department of Biology, Kastamonu University

Cite this article: Sener I, Gür M, Verep D, Güney K, Altuner EM. Antimicrobial Activities and Some Flavonoids in Extracts of Some Medicinal Plants. Indian J of Pharmaceutical Education and Research. 2017;51(3)Suppl:S234-38. 